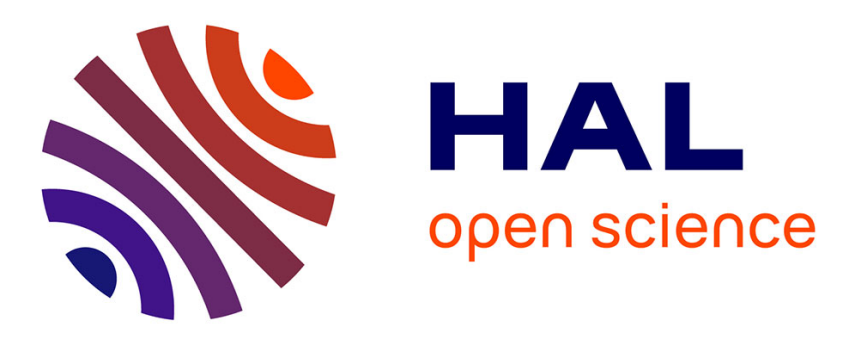

\title{
Beyond the territorial fix: regional assemblages, politics and power
}

John Richard Allen, Allan Cochrane

\section{To cite this version:}

John Richard Allen, Allan Cochrane. Beyond the territorial fix: regional assemblages, politics and power. Regional Studies, 2007, 41 (09), pp.1161-1175. 10.1080/00343400701543348 . hal-00514690

\author{
HAL Id: hal-00514690 \\ https://hal.science/hal-00514690
}

Submitted on 3 Sep 2010

HAL is a multi-disciplinary open access archive for the deposit and dissemination of scientific research documents, whether they are published or not. The documents may come from teaching and research institutions in France or abroad, or from public or private research centers.
L'archive ouverte pluridisciplinaire HAL, est destinée au dépôt et à la diffusion de documents scientifiques de niveau recherche, publiés ou non, émanant des établissements d'enseignement et de recherche français ou étrangers, des laboratoires publics ou privés. 


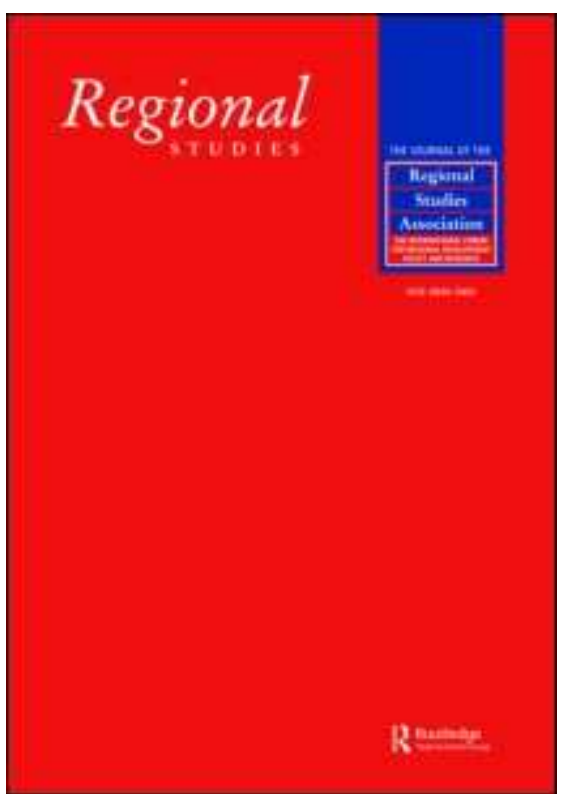

Beyond the territorial fix: regional assemblages, politics and power

\begin{tabular}{|r|l|}
\hline Journal: & Regional Studies \\
\hline Manuscript ID: & CRES-2006-0253.R1 \\
\hline Manuscript Type: & Main Section \\
\hline JEL codes: & $\begin{array}{l}\text { R5 - Regional Government Analysis < R - Urban, Rural, and } \\
\text { Regional Economics }\end{array}$ \\
\hline Keywords: & region, assemblages, power, politics, governance, networks \\
\hline
\end{tabular}

\section{SCHOLARONE \\ Manuscripts}




\section{Beyond the territorial fix: regional assemblages, politics and power}

John Allen and Allan Cochrane, Faculty of Social Sciences, The Open University, Milton Keynes MK7 6AA

j.r.allen@open.ac.uk

a.d.cochrane@open.ac.uk

Final submission for Regional Studies Special Issue, Whither Regional Studies?

February 2007

The Open University

Faculty of Social Sciences

Geography Department

Walton Hall

Milton Keynes

MK7 6AA

UK 


\begin{abstract}
The idea of regions as territorially fixed in some vital political sense is a stubborn conception, one that is both mobilized to pursue selective interests and to establish regional identities. To assert that regions are political constructs, however, is not to say that such bounded, territorial entities enclose all the political relations which produce them. This paper puts forward a relational view of the region based upon an assemblage of political actors, some public, some private, where elements of central and local government are 'lodged' within the region, not acting above or below it. Using examples drawn from governing agencies across and beyond the south East of England, we show how a more diffuse form of governance has given rise to a spatially discontinuous region. This is grounded in an exposition of the political assemblage that is Milton Keynes today, with its provisional, cross-cutting mix of institutional agencies, partnerships, businesses and interest groupings engaged in a 'politics of scale' exercise to fix the region.
\end{abstract}

\title{
Key Words
}

region, assemblages, power, politics, governance, networks

\section{JEL codes:}

R50 - Regional Government Analysis R58 - Regional Development Policy 


\section{Introduction}

In Rethinking the Region (ALLEN et al, 1998), we (and Doreen Massey) were at pains to stress that regions are 'a series of open, discontinuous spaces constituted by the social relationships which stretch across them in a variety of ways' (p. 5). They are formed out of a nexus of relations and connections, much of which takes its shape from elsewhere. In today's language, regions are a product of networked flows and relations fixed in a more or less provisional manner. Our concern was to show the South East of England as a neo-liberal heartland, the product of overlapping social, political and economic relations which stretched across space in ways that showed little or no respect for the regional boundaries imposed upon them. Massey has gone on to emphasise the importance of understanding 'space as an open and ongoing production' (MASSEY, 2005, p. 55), rather than trying to capture it as some fixed expression of territory. This relational approach is consistent with a number of other attempts to capture the uncertain ways in which regions are created and recreated through networked social relationships (see, for example, AMIN, 2004, PAASI, 2001).

Yet such attempts have clearly not dispelled the doubts and suspicions that the case against a vision of bounded, territorially fixed regions has been exaggerated (see JONES and MACLEOD, 2004). Perhaps understandably, the urge to draw lines around spatial regions, to know the limits of political authority, is one that is not easy to stifle. It does, after all, chime with many everyday political practices in a way that the symbolism of a more diffuse, somewhat nebulous, regionalism does not. Indeed, we were only too aware that our conceptualization of the region sat uneasily with attempts to define or understand regions through clusters of connected economic activities - as pre-existing 'crucibles' of growth (WARD and JONAS, 2004 explore similar issues). We were also markedly conscious that it fits still more uneasily with visions of regions as territorially bounded 
political constructions through which traditional forms of electoral accountability can be delivered. Much of our argument, it has to be said, was couched in economic terms growth mechanisms, neo-liberal market forces, and such - which fit well with the language of network and flows. Rightly or wrongly, however, political institutions, lend themselves to the language of territory, fixity and boundaries. They evoke a sense of embeddedness in their performance and practice, one that is echoed in recent discussions about the potential of regional politics (where the drive to elected assemblies in England - mimicking the 'regional' structures of Europe, Germany, Spain and maybe even French decentralisation - nonetheless ended in failure for the regional agenda when the North East of England voted against such an assembly) (see RALLINGS and THRASHER, 2006).

Even with the onset of a more pluralist governance discourse and the wider range of institutional actors that such a shift entails, we would argue that the territorial focus has remained much the same, despite a more flexible spatial vocabulary that speaks about regionalisation and the re-scaling of the state. While a focus on territoriality may not necessarily imply the existence of fixed and stable boundaries (see, e.g., MORGAN, 2002) in many respects the vocabulary has remained trapped within a framework that attempts to identify new territorial settlements, even if the size and nature of the territories has changed, from neighbourhoods - and parishes - to city-regions and beyond, with some suggesting that city-regions may provide the basis for a new territorial political fix, albeit with 'fuzzy' boundaries and through the building of 'coalitions for change' rather than the creation of new institutions through structural reform (HARDING et al, 2006, p.37). The British government's White Paper on local government published in 2006 similarly celebrates the existence of city-regions while offering little in practical terms beyond support for 'multi-area agreements' between local councils 


\section{(DEPARTMENT FOR COMMUNITIES AND LOCAL GOVERNMENT, 2006). Even if} it is recognised that no particular scale currently has 'primacy', there seems to be an expectation that this is just a transitory phenomenon (see, e.g. JESSOP, 2006a).

It would seem that the language of territorial politics is not only stubborn, but equally that it cannot simply be wished away by some conceptual wand, since it is itself a powerful political construction (HUDSON, 2006; JONES and MACLEOD, 2004; PAASI, 2002, 2004). Assemblies, regional development agencies, and the like, are performed as territorial entities which try to hold down the fluid elements of global life in the general interest of their 'regions' - seeking to generate fixity 'through processes of government and governance' (GOODWIN et al, 2005, p. 423). Regional political institutions define themselves in relation to 'other regions', both in order to compete for public funds and to give them an identity around which it is possible to mobilise other forms of support. In doing so, they represent themselves as coherent, collaborative entities which have to compete and learn. But, and this is to acknowledge the point, the outcome is always a political construction. The diverse ways in which the 'coherence' of a region is constructed and acted upon by different, and often new, political actors is the result of a complex set of political mobilisations at any one point in time (constructing regions as 'imagined communities') (KEATING et al, 2003). In short, as we stressed in our account of the South East of England as a neo-liberal growth region, the invention and re-invention of regions is a constant.

What appears to be less well understood, however, is that in the current political moment regions are being remade in ways that directly undermine the idea of a region as a meaningful territorial entity. As we see it, the governance of regions, and its spatiality, now works through a looser, more negotiable, set of political arrangements that take their shape from the networks of relations that stretch across and beyond given regional 
boundaries. The agencies, the partnerships, the political intermediaries, and the associations and connections that bring them together, increasingly form 'regional' spatial assemblages that are not exclusively regional, but bring together elements of central, regional and local institutions. In the process, we believe that a more fluid set of regional political relationships and power-plays has emerged which call into question the usefulness of continuing to represent regions politically as territorially fixed in any essential sense.

In the first part of the paper, we restate our sense of regions, and specifically the South East of England, as relational yet interdependent spaces which are open to reinvention as politically meaningful spatial entities. In particular, we try to show how, of late, a set of governing agencies across and beyond the South East have mobilized around a more discontinuous definition of 'the region' to secure their political and economic agendas. Following that, we address some of the more recent networked governance structures that have been put in place, both regionally and nationally, and the role played by political and business intermediaries who 'run' the networks by brokering connections, 'transferring' policies and, more generally, mobilizing interdependencies. Tangled and cross-cutting in their relationships, the actions of these 'regional elites' or, perhaps more accurately, quasi-elites, arguably underpin much of what passes as 'multi-level governance' and would perhaps be better captured by the mix of distanciated and proximate actions that constitute more recent forms of networked regional governance. In the third section, we attempt to illustrate the complex spatiality of contemporary governance structures through the networked mobilizations that have reinvented the 'regional' politics of Milton Keynes since the 1990s. More pointedly, we hope to show that regional polities no less than regional economies may be seen to take their shape 
from the open, discontinuous spaces that we call 'the region'. Finally, we draw out some of the implications of this view for what may be termed 'regional' assemblages of power.

\section{The reinvention of the South-East of England}

Elsewhere we have forcefully argued that, in the 1980s and 1990s, the 'South East' was best understood as a 'growth' region and specifically a region of neo-liberal growth (ALLEN et al, 1998). Its national dominance was expressed through this understanding which reflected a particular confluence of political, cultural and economic dynamics (see also, AMIN et al, 2003). Although the South East was presented as a model of deregulated growth, in practice it relied on a high degree of state intervention, both to achieve particular forms of 'deregulation' which tended to advantage the South East and to deliver significant investment in large scale infrastructure (for example, investments associated with road construction, from by-passes to the M25, the outer circular road around London). In other words, if this was a 'neo-liberal' region it was not some sort of inevitable outcome of inexorable global market forces but was rather the product of a clearly articulated state strategy, which was underpinned by substantial investment in social, as well as economic, infrastructure. In this discussion, it is important to restate that the 'South East' with which we are concerned is not limited to the government region'; that is, the 'region' of the regional assembly, the government office or the regional development agency. We continue to approach the South East through its status as a growth region and the cross-cutting social and political, as well as economic, dynamics associated with that understanding. This means not only that it stretches far beyond the 'standard' region for some forms of economic and cultural relationships (for example it reaches to Cambridge through the threads connected to the high technology industries and likewise is pulled towards Wiltshire by the strands of the luxury - 'country' - housing market, as well as embracing the M4 corridor), but also that there are substantial spatio- 
social discontinuities within it - holes and hot spots (the holes represented by many of the cities and towns on the coastal fringe, such as Hastings and the Isle of Wight, as well as the old mining areas of North Kent, the legacies of Fordism such as Slough and Luton, and the hot spots represented by Gatwick airport, developments around Heathrow, the Western 'edge' and the new town of Milton Keynes).

From this perspective, the region itself is territorially discontinuous, in the sense that some places officially defined as being in the South East turn out not to be (for example, much of Kent and the coastal South, see also ROBSON et al, 2006) while other places located far away from the accredited borders of the region should be seen as part of it, precisely because they are so tightly connected through dense networks of economic and cultural relations. Such a claim is perhaps less contentious these days as material developments have prompted reflections which focus on the identification of a 'Greater South East'. In some respects, our interpretation of the region is consistent with the approach adopted by GORDON $(2003,2004)$, who has argued strongly for the identification of a 'greater' South East as a super region, as 'a regionalized version of London' (GORDON 2004, p 41). In a similar vein, drawing on evidence from the 2001 Census DORLING and THOMAS (2004) have sought to reinterpret the South East as a newly emergent metropolis, while HALL et al (2006) have identified it as a global ‘polycentric metropolis' or ‘polycentric mega-region' - a polycentric urban system. Although BUCK et al (2002) are primarily concerned with London, they, too, confirm that the economic strengths of the metropolitan region are associated with the region's fringes as much as its core. There is, of course, still a danger in all this that the task is defined as being to identify some new, more or less fixed, set of boundaries for this emergent region and we remain sceptical of any such attempts, even as the boundaries are shifted ever further outwards. 
More significant, to our mind, is the fact that the limitations of the official region are not merely of theoretical concern, but are also reflected in the practical challenges faced by regional institutions and their parent organisations across and beyond the South East. The fundamental problem of seeking to contain dynamic growth in formal structures of territorial governance, for instance, is reflected in recent plans for 'sustainable communities' which, in turn, have led to the identification of 'sub-regions' that cut across official regional boundaries. Strategies have been developed for growth sub-regions in Ashford, the Thames Gateway, Milton Keynes and the South Midlands, and the LondonStansted-Cambridge-Peterborough corridor (OPDM, 2003; ODPM, 2004). In practice, however, only Ashford, can be contained within the official region and its linkages are predominately into Europe. The Thames Gateway incorporates parts of the South East, the East of England and London; Milton Keynes and the South Midlands stretches across the South East, the East of England; London-Stansted-Cambridge-Peterborough reaches across London and the East of England. Even the documents produced within the frame of the official regionalism increasingly acknowledge the significance of what they call the Greater South East (see, for example, SEEDA 2006, p.8) or what is (more dismissively it seems) labelled a super-region by those seeking to foster development in the city-regions clustered around England's 'core cities' beyond the reach of London (see, for example, MARVIN et al 2006, pp. 44-5).

Indeed, MARVIN et al (2006) argue that the current position is one in which there is an 'implicit' regional strategy which tends to benefit the so-called 'London super-region'. The main drivers of this unspoken strategy are identified as responses to 'market failure', which are specifically expressed in initiatives such as the Sustainable Communities Plan and associated with infrastructural investment intended to ensure that there is sufficient 'affordable' housing for key workers in the region (see, e.g., RACO, 2006). Moreover, 
'place blind' investments in key areas such as higher education and research tend apparently to favour the region because of its concentration of elite knowledge based institutions, as do investments which reflect London's special national status (most recently expressed in those associated with the 2012 Olympics, but also apparent, for example, in airport investment). Even before the arrival of the Olympics, the scale of the investment in 'sustainable development' promised for the Thames Gateway far outstripped anything promised for any of England's other urban areas (RACO, 2005).

Yet, to all intents and purposes, what such reflections add up to is an attempt to 'contain' the sprawling effects of growth within larger bounded regions, whether labelled 'great' or 'super' in style.

Somewhat paradoxically, however, the new - more explicitly - regionalised structures that have emerged in England over the last ten years have actually served to strengthen the South East's position, precisely because of the way that regional actors have re-imagined themselves as players within this changing settlement. Politically motivated definitions of the region have consolidated around a new, more or less bounded, vision of the South East and its 'sub-regions'. For the first time it would seem, the South East has had to be actively constructed as a 'region', rather than simply be the place through which the nation is defined (see, for example, AMIN et al, 2003, COCHRANE, 2006a, b). The regionalisation of the South East - its re-imagination as a region - has opened up spaces for new policy actors and has also, in effect, led to the 'region' playing a rather different role within the policy imaginary that constitutes the UK. Nationally, the South East is constructed as a key driver of economic success; within the EU it is repositioned as a metropolitan region under pressure to maintain and improve its competitive position and specifically to transform itself into a knowledge economy; globally, of course, it is presented as facing dramatic challenges from the newly emergent 
city regions of Pacific Asia (see COCHRANE, 2006a). Just as some regions have been recast as underperforming and so in need of renewal, so the South East is increasingly presented as the model for the rest (PIKE et al, 2006b, FOTHERGILL, 2005).

In this context, the political driving force of the new regionalism is clear. The strapline of the South East of England Development Agency (SEEDA) promises that it is 'Working for England's World Class Region', yet also emphasises that the South East is the 'driving force of the UK's economy' or the 'powerhouse of the UK economy' (see also, MUSSON et al 2002, SEEDA 1999, 2002a, b). In other words, the drive to regional competitiveness is identified as a British as well as a global imperative. Likewise, the aim of the South East's Regional Economic Strategy for $2002-2012$ is to ensure that the region is acknowledged to be one of the fifteen 'top performing regional economies' in the world (SEEDA, 2002b, p. 8) and if it fails to claim its rightful place among Europe's elite regions then, it is implied, the UK (and the UK's other regions, cities and devolved nations) will also suffer. The most recent Regional Economic Strategy is perhaps somewhat less confident about the position of the South East, identifying it as one of the 'most prosperous regions globally', but performing relatively weakly against them and facing a series of challenges (SEEDA, 2006, pp 7-8, 21-28). Nevertheless, the overall vision remains upbeat - to ensure "that the South East will be a world class region achieving sustainable prosperity' (SEEDA, 2006, p.29).

What this amounts to, in our view, is that the South East, or rather its governing agencies, have learnt to mobilise the language of regionalism in order to justify an active growth politics, albeit one suitably moderated to incorporate the demands of sustainability, itself mobilised politically by residents keen to preserve the amenities of the Home Counties. This is a political process through which differences are negotiated without ever being made explicit or subject to open political challenge. In this context, 
the South East's county councils sponsored the Institute of Public Policy Research (IPPR) to undertake a Commission on Sustainable Development in the region with an agenda focused not only on the maintenance of regional prosperity, but also on the enhancement of its environment and the improvement of the quality of life of its residents. The significance of this initiative is that it provides political weight aimed at moderating the impact of the growth agenda - a means of avoiding accusations of 'nimbyism' by mobilising environmental and other arguments (see, for example, FOLEY, 2004, EVERY and FOLEY, 2005, COMMISSION ON SUSTAINABLE DEVELOPMENT, 2005). Similar concerns have found their way into the more formal language of the Integrated Regional Framework prepared on behalf of South East Regional Assembly (SEERA) and a range of other agencies, including the Government Office of the South East (GOSE), SEEDA, the Environment Agency and the Department of Health (see SEERA et al, 2004).

Above all, this has involved a process of negotiation between government and regionally based agencies which, in the process of mobilizing around spatial approximations of the region to steer decisions in their favour, distend and distort the geographies of the South East to suit their own political ends. In doing so, however, they seem to deny the territorially discontinuous nature of the regional inventions, which they themselves perform and operate through. Ironically, this perhaps can itself be seen as the product of newly emerged regional governance structures that have led to, and indeed reflect, more tangled arrangements of power.

\section{New political arrangements}

SANDFORD (2005) is persuasive in suggesting that the new regional governance institutions in England have, in a relatively short time period, become a taken for granted feature of sub-national governance throughout the country and not just in the traditional 
'regions', those which have been identified as 'distressed areas' since the 1930s. While there has clearly not been a devolution of political authority along the same lines as in Scotland or Wales, what is emerging elsewhere is a more fragmented collection of institutions and agencies whose members come together in a series of networked relationships, fostered through involvement in formal and informal forums. There is, in Sandford's view, increasing evidence that 'a distinctive system of governance is developing in the English regions' (SANDFORD, 2005, p.2) based around relationships of this sort, rather than traditional structures of government. Indeed, he goes on to argue that it is possible to identify a series of relatively autonomous institutions of the region, such as regional networks, regional development agencies and regional chambers (made up of local authority representatives and representatives of business, the voluntary and community sectors), as well as government agencies which are located within its spatial remit, yet remain directly responsible to the centre.

Across the South East of England a range of governance agencies has emerged of late, some more explicitly engaged in making up the region and defining their own role within it than others, which survive and operate within the context of more diffuse and fragmented forms of governance. The existing governance structures of the Greater South East include an elected assembly and elected mayor in London, regional chambers supposedly representing 'stakeholders', three regional development agencies, three regionally based central government offices, regional and London-wide local government associations, and much more. But this fragmentation does not necessarily mean that the arrangement is politically muddled. On the contrary, the nature of the overlapping and intersecting sets of formal and informal institutional arrangements helps to ensure that the broad direction of policy is more or less taken for granted, in a form that JESSOP (2004) calls 'metagovernance' yet without the necessity for a 'metagovernment'. Such political 
coherence, however, is not matched by an equivalent regional coherence. It would seem that a spatial tension has been 'built in' to the new governance arrangements where the more networked forms jostle with the new territorial imaginaries of the South East.

In fact, the search for bounded territories, within which electoral accountability may be constructed or state authority mobilised, has actively understated the emergence of different sorts of politics and forms of governance. In practice, it has proved impossible to construct institutional arrangements that can be captured by existing regional boundaries. This is perhaps most immediately apparent in the creation of a number of cross-regional planning areas and partnership agencies in the context of the central government sponsored Sustainable Communities Plan, whose ambition is to deliver housing on a scale that is capable of underpinning continuing 'regional' and thus national growth (ODPM 2003). Arrangements in the major growth areas, as noted, stretch across existing regional boundaries and link together government departments, government sponsored agencies and new 'partnership' institutions (including a series of so-called local delivery vehicles), although none of them are fixed or set in their geography. Again, we are witnessing political relationships and linkages which stretch beyond and cross-cut the official region's already porous boundaries.

It is tempting to believe that these emergent arrangements may constitute or provide spaces of representation for regional elites, but this would be to exaggerate the status of such elites, as well as implying that we are seeing the creation of a more homogeneous, regionally based economic and political formation than exists in practice. As JOHN et al (2002, p. 734) confirm, 'elite networks rarely identify with the South East region, nor do they mobilize behind regional institutions' (see also COCHRANE, 2006b). Instead it may be better to think of the new political actors as forces operating in a looser, less centred 
system, mobilizing through networks rather than through conventional hierarchical arrangements.

Within this more complex spatiality of governance, professional 'elites', including the growing band of consultants (not for profit, like the IPPR, as well as private), increasingly act as intermediaries brokering connections or translating policies between agencies, to deliver the politics of the day to day by 'facilitating' different interests and activities (SANDFORD, 2005). Less obvious in terms of their role in 'directing' operations and more distanciated in their relationships than traditional elites, the regional professionals nonetheless share a similar positioning in the new forms of governance to facilitators, brokers and policy assemblers (see also the discussion of what he calls the 'regional service class' in LOVERING, 1999). It is this which increasingly gives them their status as part of the wider governance structures.

\section{Multi-level governance and beyond}

One attempt to capture these new developments draws upon the notion of multi-level governance, a concept borrowed from political science and, in particular, from debates generated by the experience of the European Union and, more specifically, the working of the structural funds (see BACHE and FLINDERS, 2004, HOOGHE and MARKS, 2003, WARLEIGH, 2006). It implies not only that 'governments' exist at a range of different geographical levels or scales, but also that they are increasingly interdependent and involved in a continuing process of negotiation across a range of policy fields. The notion of multi-level governance goes further to suggest that it is not just governments that matter, but also the relationships between, and the interdependence of, governments and non-governmental organizations and agencies. This approach seeks to locate the formal institutions of government alongside, but also within, more complex forms of networked governance. 
In that respect, multi-level governance provides a starting point to think about emergent forms of regional politics, although its limitations as an explanatory device quickly reveal themselves. One relates to its continued focus on relationships between governments; in other words, the significance of governance as a form of governing within which a range of actors, including but not exclusively governments, may be engaged, loses its force as the process is reinterpreted as one defined through intergovernmental relations. Similarly, the continued focus on levels of government positioned within nested hierarchies and the emphasis on forms of vertical interdependence tends, as Jessop notes, to underplay the 'tangled and shifting nature of dominant, nodal, and marginal levels of government in different areas' (JESSOP, 2006b, p. 151, also 2005). Jessop himself favours the use of the term multi-scalar governance as an alternative, although some of the same criticisms that he directs at multi-level governance can be levelled at the alternative if the (geographical) term 'scale' is simply substituted for the (institutionalist) term 'level', since 'scales' and 'levels' are too often understood as fixed, rather than relational concepts.

It is, however, difficult to avoid the fact that no matter how malleable the concept of scale has become - even when understood relationally - there is an implicit hierarchization of space that makes it difficult to entertain the kinds of transverse connection mobilized by the professional and business elites who configure the new governance arrangements. Geographical scale, as an ordering concept, is not without its uses as an indicator of the limits of jurisdictional or administrative spatial authority, but too often it is overextended in its use to frame processes that exceed or cross cut scalar boundaries (see BRENNER, 2001; JONAS, 2006; MARSTON et al, 2005). At worst, scale is used to pre-define the boundaries of institutional activity before the political relationships and connections have been traced and understood. In trying to capture and 
understand something like the development of fast policy transfer, for example, where ideas are brokered between agencies and institutions in ways that belie regional boundary markers, a scalar ontology of whatever kind would produce a rather foreshortened version of events (see, for example, PECK's account of the 'transcalar slipperiness of workfarist discourses and practices', 2002, p357). Even as the 'region' of the South East is redefined in policy discourse, the more mediated relationships between different bodies, partners and organizations multiply the possibilities for political intervention at different moments and within a range of institutional settings that loosen defined distances and scaled territories (see ALLEN, 2004).

This, then, is to recognize that an ongoing 'politics of scale', where politicians and professionals mobilize around a particular spatial representation of the region and act upon it, does not mean that the actual spatial forms of governance are also contained within the boundaries of the reinvented region. The two forms of political mobilization represent quite different kinds of power-play and lead to the possibility of different types of political opportunity. The belated construction of the 'official' South East as a 'region', for instance, has opened up a different kind of geographical potential for the region. In the past, the debate about regional policy has focused on differences in wealth between regions, but now each region has the task of identifying its own problems of social exclusion that need to be tackled. This brings with it the possibility of finding new ways of mobilizing resource through the new machineries of governance. We have already noted the way in which the most recent SEEDA strategy focuses on the 'challenges' the region faces, but intraregional inequality has also become a significant focus of attention. A sharp contrast is drawn between the region's Western growth belt and its coastal fringes to the East and South which face problems of decline (in both tourism and other traditional industries). The old mining areas of north Kent and others with concentrations 
of declining industries, particularly those associated with defence or port activities, are also identified as suitable cases for policy intervention (see, SEEDA, 2002b, pp12-14). In this context, therefore, there is an explicit focus on 'tackling disadvantage' within the region (as the politics of the regional begging bowl finds an expression even in England's most prosperous region) at the same time as any discussion of redistribution between regions is more or less explicitly removed from the agenda (thus making explicit the implicit national strategy identified by MARVIN et al, 2006. See also FOTHERGILL, 2005).

Were it not for the new machineries of governance, however, such political strategies might not have evolved in quite this manner. In the next section, we outline in greater detail the particular spatial assemblage of governance that has shaped the politics of a key site in the overall vision of a 'stretched' South East; namely the recent experience of Milton Keynes.

\section{The new politics in practice: the Milton Keynes experience}

Milton Keynes has a place at the centre of the (whether implicit or explicit) national regional strategy embedded in the Sustainable Communities Plan (ODPM, 2003), and it has played a similar role in the South East since the late 1960s - as a growth pole even as other parts of Buckinghamshire resisted growth (see, e.g. BENDIXSON and PLATT, 1998, pp. 1-32, CHARLESWORTH and COCHRANE, 1994, CLAPSON, 2004). The Sustainable Communities Plan builds on this by identifying a Milton Keynes and South Midlands sub-region which stretches from Corby in the North to Luton in the South and from Bedford in the East to Aylesbury in the West. This is a 'sub-region' that cuts across three sets of official regional boundaries. Milton Keynes (with a current population of $212,000)$ is expected to make a substantial contribution to the population growth targets for the sub-region, doubling in population to around 400,000 by 2030 . 


\section{INSERT FIGURE 1 HERE}

The context for the development of public policy in Milton Keynes over the next few decades is set out in the Sub Regional Strategy for Milton Keynes and the South Midlands (see GOSE et al, 2004) which forms the planning framework for the delivery of the Sustainable Communities Plan. Formally, the Sub Regional Strategy is being directed by the Government Offices of the South East, East of England and East Midlands, and an inter-regional Board, chaired by a Government Minister, has been established to steer it. The expectation is also that the three Regional Development Agencies - the South East of England Development Agency (SEEDA), the East of England Development Agency (EEDA) and the East Midlands Development Agency (EMDA) - will work closely together in its implementation, with SEEDA taking specific responsibility for Milton Keynes. In other words, the formal 'regional' structures are already pretty complex.

That, however, is just one institutional layer, albeit a most significant one. It is overlain on an institutional landscape in Milton Keynes which is littered with partnerships of one sort and another. Some of these (such as the Parks Trust and Community Foundation, the Central Milton Keynes Partnership) are legacies of the new town Development Corporation (itself a state sponsored development agency which reached the end of its life in 1992, but left significant local land holdings in the hands of English Partnerships). Others, such as the Milton Keynes Economy and Learning Partnership (MKELP), a business led partnership organization, and Milton Keynes Local Strategic Partnership (MKLSP) which is responsible for preparing Milton Keynes'own community strategy, are the product of more recent political negotiations. The Milton Keynes Partnership (MKP) has been set up as a local delivery vehicle for the Sustainable Communities Plan, itself absorbing the Central Milton Keynes Partnership (whose task is 
to oversee the remaking and further development of the central shopping and office district). This is a world in which the rhetoric of 'community' and 'partnership' is mobilised unproblematically to produce apparently shared agendas, masking the possibility of significant conflict over alternative visions of change (see, e.g., COCHRANE, 2007, pp. 48-67).

The division of labour between the various bodies in the field of economic development is not altogether clear, but can be outlined as follows. MKELP presents itself as an autonomous agency with a specific remit - namely to 'promote and develop a prosperous community, underpinned by a strong economy with employment and learning opportunities for all' (MKELP, 2004). It has a small secretariat of its own and is a publicprivate partnership, apparently led by the private sector (even if, in practice, its membership remains dominated by representatives of public sector agencies of one sort or another). MKELP was responsible for commissioning work on developing an economic strategy for Milton Keynes, but has also played an important part, with other Economic Partnerships and the relevant RDAs, in developing yet another sub-regional vision in the form of the Oxford to Cambridge Arc (which is identified, perhaps unsurprisingly with the help of a set of consultants, as a knowledge economy cluster that cuts across MKSM from East to West, see, SQW, 2001). MKLSP has been set up along the lines identified in government guidance (see, DETR, 2001), as the mechanism through which a 'community plan' for the area could be developed, drawing on a wider membership than MKELP, including representation of community groups and a range of partnerships in social areas such as housing, transport, health, children and young people, childcare and the environment. The local authority was a driving force in its formation because of the perceived need to co-ordinate local strategies - in particular linking different aspects of employment policies such as training, childcare, housing and transport - but more 
importantly to provide a forum through which the local political agenda could be given additional legitimacy. The Local Strategic Partnership was intended to play a major role in establishing a negotiating position with central government about budgets and local authority funding settlements (interview with Council Representative on LSP Board, March 2005) (COCHRANE and ETHERINGTON, 2007).

If both of these partnerships can be identified as 'local' - the products of negotiations between local actors, even if both also incorporate representatives of government agencies, such as English Partnerships, SEEDA, GOSE and the Learning and Skills Council - then MKP is more clearly the product of a national initiative, in the context of the Sustainable Communities Plan. It is the 'local delivery vehicle' explicitly tasked with the responsibility of delivering on the housing targets set by national strategy, filtered through the sub-regional strategy prepared by GOSE et al (2004) and endorsed by the Secretary of State. This brings with it the responsibility of co-ordinating the 'development of land and infrastructure' and using the surplus generated from the increased value of land to help provide the infrastructure necessary for further development (MKPC, 2004, p. 27). MKP has development control powers for a designated Urban Development Area. Formally, there can be little doubt that MKP is located within a hierarchy of government, as an agency of English Partnerships, which itself is responsible to the Secretary of state for the Department of Communities and Local Government. However, even this relationship is not a straightforward one. The Partnership Board includes representatives of community, business, health (drawn from the MKLSP) and local government as well as 'independents' appointed by the Secretary of State, alongside representatives of English Partnerships. For long term residents of Milton Keynes, some of the features of the new 'partnership' are familiar enough - this is effectively a down-scaled version of the Milton Keynes Development Corporation, but one which now has to work in a more 
complex institutional setting than its predecessor since, in some areas, co-operation with the Council is essential as it has planning powers of its own.

The nature of the emergent political regime can be illustrated with the help of two examples. The first relates to the making of the local community plan and the second to the processes of negotiation over infrastructural development. The development and agreement of the Community Strategy through the Local Strategic Partnership (following a series of visioning events and utilizing a series of consultants, including Halcrow, Demos and First) was seen as a way of setting an agenda for the Milton Keynes Partnership as it developed its own strategy and business plan (MKLSP, 2004). Its title summarises the vision and spells out the urban 'brand', namely that Milton Keynes is The City that Thinks Differently, Embraces Evolution and Champions Change. It incorporates work already undertaken through MKELP to determine an economic vision for the future. This, too, was undertaken through consultants (this time DTZPIEDA) who prepared a plan which set out a strategy for moving the city from a 'new town' to an 'international city', seeking to position the newly expanded Milton Keynes as a globally competitive city by making it a place attractive to globally footloose industry, while also trying to encourage employers already located in the town to be less footloose (DTZPIEDA, 2004).

The issue here is not whether this is a realistic vision of Milton Keynes' future, but, rather, how it works as a political framing or reframing. If the new town was originally envisaged as offering opportunities to those relocating from the 'overcrowded' central cities, the international city is about bringing the right sort of people to Milton Keynes to ensure that it is able to grow further and better, changing the nature of the local population so that it is attractive to employers in the knowledge industries (PIKE et al, 2006a, p.72). The role of consultants is central to the process of politics in this new 
context. They are mobilised to construct the agreed agendas (or, to use their own language, the shared visions) on the basis of which the 'partners' are prepared to operate and cooperate. They rarely add anything new to the debate but feed back what they have been told by the various agencies, professionals and elected politicians that they have consulted, giving it new legitimacy or (if successful) finding ways of shaping consensus.

The intended audience for this rhetoric is not so much the potential investors and developers (although, of course, it sets the scene for business oriented boosterism and attempts to attract outside investors), but those agencies which can be relied on to provide resources to support such an agenda, in particular the Department for Communities and Local Government, the Government Office and SEEDA. It is here (echoing points made by SEERA 2006 at a regional level) that the community strategy has such an important part to play - setting out the terms on which 'Milton Keynes' is ready to play its part in achieving the growth targets set by national government - but in the process it is expected to be supported in this endeavour. It has thus become an important reference point for the later planning documents and business plans of Milton Keynes Partnership (see, GVA GRIMLEY et al, 2006).

It is in this context that negotiation over infrastructure is so important. MKP is a 'partnership' in which the lead agency and its priorities are clear, but it too provides an arena within which negotiation may and does take place, particularly around the provision of social and other infrastructure required to underpin housing growth (for example, relating to transport linkages, the provision of health and education, and even investment in further and higher education). A tariff based system, through which a levy is paid by developers on each new house to help cover the costs of infrastructural development has been agreed (MILTON KEYNES PARTNERSHIP, 2006, pp. 43-51). This income is expected to cover around 75\% of capital costs (MILTON KEYNES COUNCIL, 
2006).The emphasis of discussion in a range of partnership meetings involving MKP and its representatives is on the need for such infrastructure as a prerequisite for growth. In other words, local state actors, as well as the professionalized representatives of the business and the voluntary sectors, use the meetings as sites for negotiation over additional resource. In the year 2004-5, these issues included the need for additional investment in strategic road building, the need to retain the central station as a stopping point for Virgin trains, the need for investment in a spur line at the station to make this possible in the longer term, the need for investment in a face to face teaching (and, if possible, research) university, the need to invest in the development of the local hospital and support for a dedicated training centre for building workers associated with the local further education college (see also MILTON KEYNES PARTNERSHIP, 2006, pp. 2933). Of particular significance is the fact that these bodies have an overlapping membership through which a policy consensus on local development is developed and reproduced. Institution building in Milton Keynes is focused on constructing policy networks that facilitate closer links and increased capacities for negotiation between 'Milton Keynes' and central government, in effect constructing hybrid institutions that can be characterised as neither central, regional or local, nor as public or private. This is a 'Milton Keynes' which may appear bounded in the approach taken by the local council, but it is also a 'Milton Keynes' that can only be understood as part of the surrounding sub-region and which - as far as business is concerned (as the private sector chair of MKELP has made clear on a number of occasions) - should not be constrained by any territorial boundaries. MKELP provides a direct route through which government agencies are able to engage with representatives of business and the council, since English Partnerships (and so MKP), GOSE, Business Link, the Learning and Skills Council and SEEDA are all involved alongside the council and a range of other 'local' 
interests. Three members of the MKP board and one of the key English Partnership officers working for MKP are members of the MKELP Board. Seven members of MKELP are also members of MKLSP, one of whom is also a member of MKP, while another is the English Partnerships officer. GOSE is represented in some form on all three bodies and SEEDA on two. The cross-cutting memberships of these bodies ensure that they operate as forums for informal as well as formal negotiation, where understandings are reached, even when they are not minuted or formally recorded (for example in discussions that took place prior to the submission of a bid for infrastructural funding from the Strategic Community Fund managed by the Office of the Deputy Prime Minister in early 2005).

Whether or not this is a form of regionalised centralism, based around 'shadowy quasi democratic forms which aim to garner the advantages of networking without changing the balance of executive power between existing institutions' (SANDFORD, 2005, p. 143) is open to question. A similar understanding has been captured in the notion of the 'shadow of hierarchy' (SCHARPF, 1994) which suggests that even if the formal structures of hierarchy have been undermined, the practice of hierarchical authority may still be played out in the experience of day to day negotiation of regional politics (see, e.g., WHITEHEAD, 2003 for a discussion of the authority relationships between agencies involved in urban regeneration in the West Midlands). The danger of such an approach is that the description of a relationship is translated into what appears to be a structural explanation (albeit in the form of a 'shadow'). The evidence from Milton Keynes suggests that while the balance may not be shifting directly and explicitly, the interdependence of the actors involved makes it difficult for those with formal executive powers to achieve their ends without extensive negotiation in which a range of sources of power may be mobilised by the actors involved. 
It is not that the multiplication of actors has simply led to a more complex form of government, but that the greater opportunities for a wider range of professionals and other bodies to mediate the decision-making process and mobilize resources independently of any central authority produces a spatial politics within which it is not always possible to know what particular advantages have been conferred upon actors by the new arrangement. Overlapping sets of political relations, networked across spaces which have little respect either for institutional levels or geographical scales, pushes us to think about a more distanciated, politics of 'the region'. In doing so, we might capture more of what is happening politically around our 'regional' institutions than if we try to filter everything through a scalar imagination.

\section{'Regional' assemblages of power}

If, as we have argued, we are witnessing the emergence of a more tangled, overlapping set of governance structures across the South East, this also has implications for how we understand the different power-plays that shape the politics of the regions. In an institutional setting where it is increasingly difficult to entertain a simple central versus regional government binary as more networked arrangements disrupt traditional, hierarchical forms of regulation and co-ordination, it becomes harder to pinpoint how governing agencies mobilize to secure, modify or translate their goals. If there are 'regional' institutional assemblages, made up of part-private, part-public agencies, as well as parts of central, regional and local government 'lodged' in spaces which fall within the constructed region, then there are also fragments of state authority, sections of business and any number of partnerships and agencies engaged in a 'politics of scale' to fix resources and stabilize geographical definitions to their advantage.

Increasingly, it would seem that there is little to be gained by talking about regional governance as a territorial arrangement when a number of the political elements 
assembled are not particularly regional in any traditional sense, even if they draw on what might be called the 'spatial grammar' of regionalism. Many are 'parts' of elsewhere, representatives of professional authority, expertise, skills and interests drawn together to move forward varied agendas and programmes. The sense in which these are 'regional' assemblages, rather than geographically tiered hierarchies of decision-making, lies with the tangle of interactions and capabilities within which power is negotiated and played out (see ALLEN, 1999). There is, as we have tried to indicate, an interplay of forces where a range of actors mobilize, enrol, translate, channel, broker and bridge in ways that make different kinds of government possible. Some of this interplay takes place at arms length, mediated indirectly, some through relations of co-presence in a more distanciated fashion, and other forms of interaction are more direct in style, but together they amount to a more or less ordered assembly of institutional actors performing the 'region'.

As we have seen in the case of Milton Keynes, the presence of central government professionals in the institutional networks allows for the exercise of direct authority over plans and agendas, rather than relying wholly upon the remote imposition of targets and benchmarks. This is less government at-a-distance than the skilled negotiation of parameters, involving inducements that both steer as well as limit development possibilities. In a context where all authority is negotiated, the wider range of 'local' political actors does nonetheless open up the prospect of all manner of persuasive, and potentially manipulative, ploys to skew agendas and steer growth targets in directions that may not have been fully anticipated by 'national' actors (similar issues are explored by WHILE et al, 2004). The case of consultant agencies, many drawn from much wider geographical networks, provides but one counter to the political authority of the centre in the form of technical expertise that enables 'regional' politicians and representatives to broker a consensus among those who need to be mobilised if a particular course of action 
is to be pursued. Hence the practices of power may be less about the visible machinery of decision-making and rather more to do with the displacement of authority, the renegotiation of inducements, the manipulation of geographical scales and the mobilizations of interests to construct politically meaningful spatial imaginaries.

Crucially, we are not talking here about a political set of negotiations 'up and down' the vertical scales of government, a 'rescaling' of power and responsibility downwards or a 'jumping of scale' by 'local' agencies (see, for example, SWYNGEOUW, 2006), but rather an assemblage of central, regional and local actors engaged in a complex set of political mobilizations at one point in time. This is not to deny that there is an uneven institutional balance between different actors. It is clear that some are more dominant than others by virtue of the financial resources and decision-making powers at their disposal, whilst others rely more on their ability to mobilize opinion and interests in their favour, but all are part and parcel of a 'regional' assemblage of political power that is defined by its practices, not by some predefined scalar arrangement of power. Neither is it to deny the obvious pressures and constraints that central government agencies can and do exert over regional and local bodies, nor the role that the national state may play in sponsoring and supporting the networks that underpin such assemblages (GOODWIN et al 2005, p. 423). But it is to recognize that such power plays take place within more fluid, relational institutional settings than any top-down, territorial arrangement can fully convey (see also, HUDSON, 2006).

All this talk of networked mobilizations across the South East of England does, however, sit rather awkwardly with the long held view that power, or certainly the most powerful political agencies, are located in the region, more specifically, in London. As the seat of political power, the executive site of government, London and the South East represents not only the centre of the nation, but also the apex of political decision-making 
as its affects the regions. More often than not this capability is read-off from the 'concentration' of power that is London and the South East (see for example, AMIN et al, 2003). Such capabilities, however, represent latent rather than actual qualities of power; they refer to the effective institutional resources and decision-making abilities which can be marshalled to great effect. Indeed, there is no question as to how effective and extensive such capabilities can be and have been over time; they encapsulate all that we understand by the term, state power. But such territorially embedded assets and resources are of less help when it is the actual practices of power that we wish to understand, rather than the concentration of abilities that lie behind them (see ALLEN, 2003).

A top-down, centre-out account of central government power is an unhelpful starting point for any exploration of the practice of state power. There is a 'how' to power which is not satisfactorily answered by assertions of the unproblematic reach or delegation of 'centralized powers', where power is measured by the size of the territory which contains it. In fact, this question is all the more pressing for those who, like us, consider the governance of regions to be a predominantly relational affair, where power is a relational effect of political interaction, not a bloc of pre-formed decision-making powers or a distributed capability. In the foregoing, we have considered central government actors as part of 'regional' assemblages, not bodies which sit over or apart from the regions. Their manoeuvres and negotiations are entangled in regional governance structures, as are the effects of their actions, and it is through such relationships that the constraints and impositions of 'the centre' are likely to reveal themselves, not from afar like some remote authority or historical power bloc.

\section{Conclusion}

The purpose of this paper has been to challenge the idea of regions as fixed political spaces ordered by scale, but in doing so we are aware that we run the risk of sidelining 
the importance of a 'politics of scale', where agencies and institutions mobilize to construct a region like the South East. Our argument was not that the South East of England was simply 'unbounded', but that it, indeed any region, is made and remade by political processes which stretch beyond it and impact unevenly. To assert that regions are political constructs therefore, is not to suggest that such constructs 'contain' in some way the very governance relationship that 'invented' them. It would be wrong to collapse the two geographies, one the defined outcome of political endeavours, the other the tangled relationships which almost inevitably exceed the boundaries drawn. The likelihood of such excess is why we have tried to think through the emergence of a more diffuse and fragmented form of governance as a 'regional' assemblage, rather than as a series of regional institutions which are territorially fixed in some way.

It is worth stressing that by this we emphatically do not mean that 'regional' political institutions, or parts of them, have been networked in such a way that they no longer have a settled presence. We are not arguing that the professional and business elites owe their points of attachment to the networks rather than to the regions or that their relationships are simply embedded in flows of interaction not the peculiarities of the regional context. On the contrary, it is the 'lodging' of a wide range of political actors drawn from the national as much as the local domain which gives a regional presence to the new governance arrangements. The political assemblage is 'regional' because that is what its capabilities speak to, not because its authority is defined by territorial parameters. The precise shape, mix and membership of such assemblages is a contingent affair, as can be witnessed across the South East, and their organizational logic is a cross-cutting mix of distanciated and proximate actions.

Such arrangements, whilst relatively novel in institutional terms, also raise questions about what kind of democratic politics is compatible with them. Some, such as 
ROSENAU (2004), have argued that the new forms of governance generate democratic possibilities because they open up politics to a much wider range of actors in the form of an extended pluralism. There is, however, no simple equation between the emergence of networked forms of governance, on the one hand, and negotiation and pluralism, on the other (see HADJIMACHALIS and HUDSON, 2006). On the contrary, as our discussion of the Milton Keynes' experience suggests, these political arrangements are characterised by forms of closure in which some are licensed as stakeholders while others are consulted or only involved at one remove through forms of representation that may not allow for direct accountability (see also HUMPHREY and SHAW, 2006 for experience in another region of England). Alternative forms of democratic accountability, consistent with the more assembled forms of governance remain elusive.

Nevertheless, there are some signs which suggest that it is possible to generate new forms of engagement, utilising some aspects of the emergent political framework. So, for example, SANDFORD (2006) outlines some of the ways in which regional assemblies themselves not directly elected - have sought to position themselves as offering the possibility of civic engagement. And, as PIKE (2004) notes, there is no simple (hegemonic) approach to the management of local and regional economic development, but rather an overlapping set of policy prescriptions which he characterises as 'orthodox' and 'heterodox', with 'institutional experimentation' existing alongside a continued reliance on professional expertise. As a result, he points to the possibility of opening up the process to forms of democratic involvement, based on 'the discussion of contextsensitive and progressive alternatives based upon the inevitably messy historical evolution of orthodox and heterodox approaches, and the building of a more participatory determination of economic development priorities and policies' (PIKE, 2004, p. 2158). 
So, for example, as we have seen, the counties of the South East were able to move outside the institutional frame to commission a consultancy usually associated with the 'left' to undertake work that allowed them to question the sustainability of the drive to housing development set out in the Sustainable Communities Plan. Similarly Milton Keynes Council (again with the help of consultants) were able to mobilise the Local Strategic Partnership and its related partnerships to construct a vision for development which was intended to provide the starting point for the development planning (and infrastructural investment) to be taken on by Milton Keynes Partnership. These are merely indicative of some of the political possibilities inherent in a world of regional politics which (for good or ill) is not defined through clear-cut, scalar hierarchies of government, even if the options remain constrained by the more diffuse and tangled assemblages of governance. And wider possibilities are also raised by the strategies being developed. The regional politics of development are based around attempts to construct wider visions of change ('from new town to international city' is just one example of the slogans being mobilised to reflect this). In other words, the attempts to move beyond the negotiations about particular initiatives and to set broader ground rules within which they may be pursued also opens up scope for the generation of alternative sets of visions. In doing so, it creates the space for alternative political movements potentially from outside the charmed circle of the regional assemblage, albeit sometimes with leverage within it through existing democratic and popular institutions such as local councils, civic groups, trade unions, social movements and community organisations. 


\section{Acknowledgement}

We would like to thank Andy Pike and Doreen Massey for their insight and comment on many of the ideas presented in this paper, as well as those provided by the anonymous referees. The usual disclaimers apply.

\section{References}

ALLEN, J. (1999) Spatial assemblages of power: From domination to empowerment, in MASSEY, D., ALLEN, J. and SARRE, P. Human Geography Today. Polity Press, Cambridge.

ALLEN, J. (2003) Lost Geographies of Power. Blackwell, Oxford.

ALLEN, J. (2004) The whereabouts of power: Politics, government and space, Geografiska Annaler 86B, 19-32

ALLEN, J., MASSEY, D. and COCHRANE, A. with CHARLESWORTH, J., COURT, G., HENRY, N. and SARRE, P. (1998) Rethinking the Region. Routledge, London. AMIN, A. (2004) Regions unbound: Towards a new politics of place, Geografiska Annaler, 86 B, 33-44.

AMIN, A., MASSEY, D. and THRIFT, N. (2003) Decentering the Nation. A Radical Approach to Regional Inequality. Catalyst, London.

BACHE, I. and FLINDERS, M. (Eds.) (2004) Multi-Level Governance. Oxford University Press, Oxford. 
BENDIXSON, T. and PLATT, J. (1992) Milton Keynes: Image and Reality. Granta,

Cambridge.

BRENNER, N. (2001) The limits to scale: Methodological reflections on scale structuration, Progress in Human Geography, 25, 591-614.

BUCK, N., GORDON, I., HALL, P., HARLOE, M. and KLEINMAN, M. (2002)

Working Capital. Life and Labour in Contemporary London. Routledge, London.

CHARLESWORTH, J. and COCHRANE, A. (1994) Tales of the suburbs: the local politics of growth in the South-East of England, Urban Studies, 31, 1723-1738

CLAPSON, M. (2004) A Social History of Milton Keynes. Middle England/Edge City. Frank Cass, London.

COCHRANE, A. (2006a) Devolving the heartland: Making up a new social policy for the 'South East', Critical Social Policy, 26, 685-696.

COCHRANE, A. (2006b) Looking for the South-East, in HARDILL, I., BENNEWORTH, P., BAKER, M. and BUDD, L. (Eds.) (2006) The Rise of the English Regions, Routledge, London.

COCHRANE, A. (2007) Understanding Urban Policy. A Critical Approach. Blackwell, Oxford.

COCHRANE, A. and ETHERINGTON, D. (2007 forthcoming) Managing local labour markets and making up new spaces of welfare, Environment and Planning A.

THE COMMISSION ON SUSTAINABLE DEVELOPMENT IN THE SOUTH EAST (2005) Final Report. Institute of Public Policy Research, London. 
DETR (2001 Local Strategic Partnerships. Government Guidance Summary. Department of the Environment, Transport and the Regions, London.

DTZPIEDA (2004) From New Town to International City, DTZPieda Consulting, Reading.

DEPARTMENT OF COMMUNITIES AND LOCAL GOVERNMENT (2006) Strong and Prosperous Communities. The Local Government White Paper. The Stationery Office, London

DORLING, D. and THOMAS, B. (2004) People and Places, A 2001 Census Atlas of the $U K$. Policy Press, Bristol.

EVERY, L. and FOLEY, J. (2004) Managing Water Resources and Flood Risk in the South East. Institute of Public Policy Research, London.

FOLEY, J. (2004) The Problems of Success: Reconciling Economic Growth and Quality of Life in the South East. Institute of Public Policy Research, London.

FOTHERGILL, S. (2005) A new regional policy for Britain. Regional Studies, 39, 659667.

GOSE (2005) Infrastructure in the South East. Government Office for the South East, Guildford.

GOSE, GOEM, GOEE (2004) Secretary of State's Proposed Changes. Milton Keynes and South Midlands Sub-Regional Strategy. Alterations to Regional Spatial Strategy for the East of England, East Midlands and south East of England. Government Office for the East Midlands, Nottingham. 
GVA GRIMLEY LLP with EDAW and ATKINS (2006) The New Plan for Milton Keynes. A Strategy for Growth to 2031. MK 2031 - A Long Term Sustainable Growth Strategy. Milton Keynes Partnership, Milton Keynes.

GOODWIN, M., JONES, M. and JONES, R. (2005) Devolution, constitutional change and economic development: explaining and understanding the new institutional geographies of the British state, Regional Studies, 39, 421-436.

GORDON, I. (2003) Three into one: joining up the Greater South East, Town and Country Planning, 72, 342-3.

GORDON, I. (2004) A disjointed dynamo. The Greater South East and inter-regional relationships, New Economy, 11, 40-44.

HADJIMICHALIS, C. and HUDSON, R. (2006) Networks, regional development and democratic control, International Journal of Urban and Regional Studies, 30, 858-872.

HALL, P., PAIN, K., and GREEN, N. (2006) Anatomy of the polycentric metropolis; eight mega-city regions in overview, in HALL, P. and PAIN, K. (Eds.) The Polycentric Metropolitan Region: Learning from Mega-City Regions in Europe, pp 19-52. Earthscan, London.

HARDING, A., MARVIN, S. and ROBSON, B. (2006) A Framework for City-Regions. Office of the Deputy Prime Minister, London.

HOOGHE, L. and MARKS, G. (2003) Multi-level Governance and European Integration. Rowman and Littlefield, Lanham, MD.

HUDSON, R. (2006) Regional devolution and regional economic success: Myths and illusions about power, Geografiska Annaler, 88B, 159-171. 
HUMPHREY, L. and SHAW, K. (2006) Developing inclusive approaches to regional governance in the post-referendum North East, Regional and Federal Studies, 16, 197220.

JESSOP, B. (2004) Multi-level governance and multi-level metagovernance, in BACHE, I. and FLINDERS, M. (Eds.) (2004) Multi-Level Governance, pp. 49-74. Oxford University Press, Oxford.

JESSOP, B. (2005) The political economy of scale and European governance, Tijdschrift voor Economische en Sociale Geografie 96, 225-230.

JESSOP, B. (2006a) Spatial fixes, temporal fixes and spatio-temporal fixes, in GREGORY, D. and CASTREE, N. (eds) David Harvey: A Critical Reader, pp. 142-166. Blackwell, Oxford.

JESSOP, B. (2006b) State- and regulation- theoretical perspectives on the European Union and the failure of the Lisbon Agenda, Competition and Change, 10, 141-161.

JOHN, P., MUSSON, S. and TICKELl, A. (2002) England's problem region: regionalism in the South East, Regional Studies, 36, 733-741.

JONAS, A.E.G. (2006), Pro scale: further reflections on the 'scale debate' in human geography, Transactions of the Institute of British Geographers, NS31, 399-406.

JONES, M. and MACLEOD, G. (2004) Regional spaces, spaces of regionalism: territory, insurgent politics and the English question, Transactions of the Institute of British Geographers, NS29, 433-452.

KEATING, M., LOUGHLIN, J. and DESCHOWER, K. (2003) Culture, Institutions and Economic Development. A Study of Eight European Regions. Edward Elgar, Cheltenham. 
LOVERING, J. (1999) Theory led by policy: the inadequacies of the 'New Regionalism' (illustrated by the case of Wales), International Journal of Urban and Regional Research.

23, 379-395.

MKELP (2004) Our remit, http://www.mkweb.co.uk/mkelp

MKPC (2004) Business Plan Consultation Draft Version 2 Milton Keynes Partnership Committee, Milton Keynes.

MARSTON, S.A., JONES III, J.P. and WOODWARD, K. (2005) Human geography without scale, Transactions, Institute of British Geographers, NS30, 416-32.

MARVIN, S., HARDING, A. and ROBINSON, B. (2006) A Framework for city-Regions, Working Paper 4. The Role of City-Regions in Regional Economic Development Policy. Office of the Deputy Prime Minister, London.

MASSEY, D. (2005) For Space. London: Sage.

MKLSP (2004) Milton Keynes Community Strategy. Our Handbook for change 20042034. The City that Thinks Differently Embraces Evolution and Champions Change. Milton Keynes Council, Milton Keynes.

MILTON KEYNES COUNCIL (2006) MK Tariff, Item 8, Cabinet 27 June.

MILTON KEYNES PARTNERSHIP (2006) Business Plan. 2006/7 - 2010/11. Milton Keynes Partnership, Milton Keynes.

MORGAN, K. (2002) The English question: regional perspectives on a fractured nation, Regional Studies, 36, 797-810. 
MUSSON, S., TICKELL, A. and JOHN, P. (2002) Building a world class region: regional strategy in the South East of England, Local Economy, 17, 216-225.

ODPM (2003) Sustainable Communities: Building for the Future. Office of the Deputy Prime Minister, London.

ODPM (2004) Thames Gateway. Office of the Deputy Prime Minister, London.

PAASI, A. (2001) Bounded spaces in the mobile world: deconstructing 'regional identify', Tidschrift voor Economische en Sociale Geografie, 93, 137-148

PAASI, A. (2002) Place and region: regional worlds and words, Progress in Human Geography, 26, 802-811

PAASI, A. (2004) Place and region: looking through the prism of scale, Progress in Human Geography, 28, 536-546.

PECK, J. Political economies of scale: Fast policy, interscalar relations, and neoliberal workfare, Economic Geography, 78, 331-360

PIKE, A. (2004) Heterodoxy and the governance of economic development, Environment and Planning A, 36, 2141-2161.

PIKE, A., CHAMPION, T., COOMBES, M., HUMPHREY, L. and TOMANEY, J. (2006a) New Horizons Programme. The Economic Viability and Self-Containment of Geographical Economies: A Framework for Analysis. Office of the Deputy Prime Minister, London. 
PIKE, A., TOMANEY, J. and RODRIGUEZ-POSE, A. (2006b) Local and Regional Development. Routledge, London.

RACO, M (2005) Sustainable development, rolled-out neoliberalism and sustainable communities, Antipode, 37, 324-347.

RACO, M. (2007) Building Sustainable Communities. Spatial Policy and Labour Mobility in Post-War Britain. Policy Press, Bristol.

RALLINGS, C. and THRASHER, M. (2006) 'Just another expensive talking shop': public attitudes and the 2004 Regional Assembly referendum in the North East of England, Regional Studies, 40: 927-936.

ROBSON, B., BARR, R., COOMBES, M., LYMPEROPOULOU, K., REES, J. (2006) A Framework for City-Regions. Working Paper 1. Mapping City-Regions. Office of the Deputy Prime Minister, London.

ROSENAU, B. (2004) Strong demand, huge supply: governance in an emerging epoch, in BACHE, I. and FLINDERS, M. (Eds.) (2004) Multi-Level Governance, pp. 31-48. Oxford University Press, Oxford.

SEEDA (1999) Building a World Class Region. An Economic Strategy for the South East of England. South East Economic Development Agency, Guildford.

SEEDA (2002a) An Economic Profile of the South East of England. South East England Development Agency, Guildford.

SEEDA (2002b) Regional Economic Strategy for South East England 2002-2012. South East England Development Agency, Guildford. 
SEEDA (2006) Draft RES. The Regional Economic Strategy for South East England 2006-2016. South East England Development Agency, Guildford.

SEERA (2006) A Clear Vision for the South East. The South East Plan Core Document. Draft Plan for submission to Government. South East England Regional Assembly, Guildford.

SEERA, GOSE, SEEDA, ENVIRONMENT AGENCY, DEPARTMENT OF HEALTH, SOUTH EAST FORUM FOR SUSTAINABILITY , REGIONAL ACTION AND INVOLVEMENT SOUTH EAST (2004) Integrated Regional Framework 2004: A Better Quality of Life in the South East, South East England Regional Assembly, Guildford. SQW (2001) The Oxford-Cambridge Arc. Final Report to a Group of Partners from Across the Arc. SQW Ltd., Cambridge.

SANDFORD, M. (2005) The New Governance of the English Regions, Palgrave Macmillan, Basingstoke.

SANDFORD, M. (2006) Civic engagement in the English regions: neo-corporatism, networks, new forms of governance, Regional and Federal Studies, 16, 221-238.

SCHARPF, F. (1994) Games real actors could play: positive and negative coordination in embedded negotiations, Journal of Theoretical Politics, 6, 27-53.

SWYNGEDUOW, E. (2005) Governance innovation and the citizen: the Janus face of governance beyond the state, Urban Studies, 42, 1991-2006.

WARD, K. and JONAS, A. (2004) Competitive city-regionalism as a politics of space: a critical reinterpretation of the new regionalism, Environment and Planning A, 36, 21192139. 
WARLEIGH, A. (2006) Conceptual combinations: multi-level governance and policy networks, in Cini, M. and Bourne, A. (Eds.) Palgrave Advances in European Union Studies, pp.77-95. Palgrave, Basingstoke.

WHILE, A, JONAS, A. and GIBBS, D. (2004) Unblocking the city? Growth pressures, collective provision, and the search for new spaces of governance in Greater Cambridge, England, Environment and Planning A, 36, 279-304.

WHITEHEAD, M. (2003) 'In the shadow of hierarchy': meta-governance, policy reform and urban regeneration in the West Midlands, Area, 35, 6-14. 
Figure 1 The Growth Areas 